ISSN: 2146-3042

DOI: $10.25095 /$ mufad.438707

\title{
Yeni Muhasebe Uzmanlık Alanlarının Muhasebe Eğitimindeki Yeri Ve Türkiye Örneğii*
}

\begin{abstract}
Şule YILDIZ** Nermin AKYEL ${ }^{* * *}$

\section{$\ddot{O Z E T}$}

Son yıllarda finansal raporlama ve muhasebe denetimi alanında yaşanan gelişmeler ışı̆̆ında, muhasebe mesleğinde bağımsız denetim, iç denetim-iç kontrol, varlık - şirket derecelendirme ve değerleme, kurumsal yönetim ve derecelendirme, adli muhasebe, karbon muhasebesi, çevre muhasebesi, hile denetimi, entegre raporlama, finansal raporlama danışmanliğl gibi yeni uzmanlık alanları ortaya çıkmıştır. Çalışmada, Türkiye'deki devlet ve vakıf üniversitelerinin işletme bölümlerinde verilen muhasebe derslerinin yeni muhasebe uzmanlık alanlarını içerip içermediği incelenmiştir. Çalışmanın muhasebe eğitimindeki yeni trendler doğrultusunda oluşturulacak ders planları için ilgili birim yöneticilerine kaynak oluşturacağı düşünülmektedir. Ayrıca, öğrencilerin kendilerini bekleyen yeni çalışma alanlarına yönelik derslere yönelmelerinin sağlanması ve muhasebe akademisyenlerinin de bu alanlarda verilecek dersler için kendilerini yenilemeleri ve eğitmeleri gerekliliği konusunda farkındalıklarının artırılması beklenmektedir. Alanları.

Anahtar Kelimeler: Muhasebe Eğitimi, Muhasebe Dersleri, İçerik Analizi, Yeni Uzmanlık

JEL Sinıflandirması: M00, M40, M41.
\end{abstract}

\section{The Place Of New Accounting Specialties In Accounting Education And Turkey} Example

\section{ABSTRACT}

In recent years, in the light of developments in financial reporting and accounting auditing, new areas of expertise have emerged in the accounting profession such as independent auditing, internal audit-internal control, asset-company rating and valuation, corporate governance and rating, forensic accounting, carbon accounting, environmental accounting, fraud audit, integrated reporting and financial reporting consultancy. The study examined whether the accounting courses offered in the business departments of state and foundation universities in Turkey included new accounting specialization areas. Results of this study might be a resource for the relevant department managers for the courses plans to be formed in line with new trends in accounting education. It is also expected that students will be encouraged to attend classes for new study areas that are waiting for, and that accounting academics will be more aware of the need for self-renewal and training for the lessons in these areas.

Keywords: Accounting Education, Accounting Courses, Content Analysis, New Specialties.

Jel Classification: $M 00$, M40, M41.

\footnotetext{
* Bu çalışma, 7-9 Eylül 2017 tarihleri arasında Zonguldak’ta gerçekleştirilen “Uluslararası Yönetim İktisat ve İşletme Kongresi”nde sözlü bildiri olarak sunulmuştur.

${ }_{* *}^{*}$ Dr. Öğr. Üyesi Şule Yıldız, Sakarya Üniversitesi İşletme Fakültesi İşletme Bölümü kasapoglu@sakarya.edu.tr

*** Dr. Öğr. Üyesi Nermin Akyel, Sakarya Üniversitesi Geyve Meslek Yüksekokulu nakyel@sakarya.edu.tr
} 


\section{GíRiş}

Bilgi teknolojilerindeki ve ekonomideki hılı gelişim, artan rekabet ve küreselleşme, işletmelerin muhasebe süreçlerini de etkilemiş, karmaşıklaşan işletme faaliyetlerine karşılık muhasebecilik mesleğinde yapılan işlemlerin de içeriği farklılaşarak önemi artmıştır. Özellikle kurumsal yönetim, denetim ve finansal raporlama gibi alanlarda yaşanan değişimin etkisiyle muhasebede yeni muhasebe uzmanlık alanları olarak adlandırılabilecek çalışma alanları ortaya çıkmıştır.

$\mathrm{Bu}$ değişime karşılık, meslek mensupları geleneksel muhasebe uygulamalarının yanında finansal tablo kullanıcılarının farklı talepleri doğrultusunda ortaya çıkan yeni uzmanlık alanlarına uyum sağlamak zorunda kalmaktadırlar. Muhasebecilik mesleğinde, bağımsız denetim, iç denetim-iç kontrol, varlık - şirket derecelendirme ve değerleme, kurumsal yönetim ve derecelendirme, adli muhasebe, karbon muhasebesi, çevre muhasebesi, hile denetimi, entegre raporlama, vergi risklerinin değerlendirmesi, finansal raporlama danışmanlığı gibi konularda ortaya çıkan bu yeni uzmanlık alanları, meslek mensuplarına danışmanlık hizmeti verebilecekleri yeni iş fırsatları da sağlamaktadır.

Muhasebe meslek mensuplarının bu alanlarda ortaya çıkan gelişmelere uyum sağlayabilmesi ve değişiklikleri uygulayabilmesi, bu konularla ilgili eğitim almaları ve kendilerini bu alanlarda geliştirmeleri ile mümkün olacaktır. Son yıllarda muhasebe alanında yaşanan bu gelişmeler doğrultusunda, yükseköğretimde muhasebe eğitiminin en yoğun şekilde verildiği yer olan fakültelerin işletme bölümlerinde okutulan derslerin de potansiyel birer meslek elemanı olan öğrencileri bu yeni iş alanlarına en iyi şekilde hazırlayacak şekilde güncellenmesi ve ders içeriklerinin bu yönde geliştirilmesi oldukça önemlidir.

$\mathrm{Bu}$ kapsamda çalışmanın amacı, muhasebe mesleğindeki yeni uzmanlık alanlarına yönelik üniversite düzeyindeki muhasebe eğitiminin mevcut durumunun ve işletme bölümleri ders plan ve programlarında gerekli derslerin verilme düzeyinin tespitidir. Çalışmanın, öğrenciler açısından kendilerini bekleyen yeni çalışma alanları hakkında bilgi edinmeleri ve bu alanlara ilişkin derslere yönelmelerinin sağlanması, muhasebe akademisyenleri açısından ise muhasebe eğitimindeki yeni eğilimler doğrultusunda verilecek dersler için kendilerini yenilemeleri ve eğitmeleri gerekliliğinin farkına varmaları noktasında fayda sağlayacağı düşünülmektedir. Ayrıca, ortaya çıkan sonuçlar üniversitelerin ilgili birim yönetimleri için, ders plan ve programlarında yeterli ölçüde yer almayan yeni muhasebe uzmanlık alanlarına yönelik derslerin artırılması konusunda kaynak oluşturabilecektir.

\section{YENI MUHASEBE UZMANLIK ALANLARININ GELIŞIMI}

Son dönemlerdeki uluslararası gelişmeler ve yeni 6102 sayılı TTK kapsamında, muhasebe mesleğinin sorumluluk alanları da genişlemiş, muhasebe sadece kayıt ve vergi odaklı bilgi hazırlayan bir sistem olmaktan çıkarak işletmenin çevresindeki tüm gelişmelerden etkilenen ve kendini yenileyen bir sistem haline gelmiştir. $\mathrm{Bu}$ değişim içinde muhasebe eğitiminde sadece temel muhasebe ilke ve kurallarına ilişkin bilgi yeterli olmayıp, mesleğin uygulanmasında meslek elemanının denetim, finansal raporlama standartları, entegre raporlama, çevre muhasebesi, maliyet yönetimi ve muhasebe bilgi sistemi gibi konularda mesleki uzmanlaşmasının önemi artmıştır. 
$\mathrm{Bu}$ uzmanlık alanları içinde bağımsız denetim, yeni koşulların muhasebe mesleğinde gerektirdiği değişiklik ve yeniliklerden en bilineni olmakla birlikte muhasebe mesleğinin yeni uygulama alanları bağımsız denetim ile sınırlı değildir. Bağımsız denetime ilişkin yapılan düzenlemeler, şirketlerde başta iç denetim ve iç kontrol sistemleri olmak üzere yeni sistemlerin ve komitelerin kurulmasını, varlı ve firma değeri ile ilgili değerlemeler yapılmasını, kurumsal yönetim uygulamalarına yönelmeyi, çeşitli konularda danışmanlık alma ve kredibilite ölçtürme gibi yeni hizmetlerin talep edilmesini hızlandırmaktadır (Sayar ve Karataş, 2017:18).

Muhasebede yeni uzmanlık alanları olarak nitelendirilebilecek bu konular çalışmada, denetim, muhasebe standartları, çevre muhasebesi, değerleme, muhasebe bilgi sistemi ve stratejik maliyet yönetimi adı altında altı başlık altında değerlendirilmiş ve aşağıda her bir uzmanlık alanına kısaca değinilmiştir:

\section{Denetim}

Güvenilir, kaliteli finansal bilgi ve raporlama, ekonomik kararların verilmesinde işletmeler ve ilgili taraflar arasındaki ticari ilişkilerin sağlıklı yürütülmesinde önemlidir. İşletmelerin finansal bilgilerinin doğruluk ve güvenilirliğinin güvencesi, etik kurallara ve mesleki standartlara uygun olarak yürütülen bağımsız denetim mekanizmasına bağlıdır (Kavut ve Adiloğlu, 2016:35).

Son dönemlerde muhasebe manipülasyonlarından kaynaklı Enron, Parmalat ve Worldcom gibi şirket skandallarının ortaya çıkması, hile tespit etmede ve önlemede denetim mesleğinin ve denetçi sorumluluklarının yeniden ele alınmasına neden olmuştur. Özellikle dava desteği, hile denetimi ve uzman şahitlik hizmeti sağlayan adli muhasebe mesleği, iç denetçi ve iç kontrolör ile birlikte muhasebe mesleğinde denetim alanında gündeme gelen yeni uzmanlıklar arasındadır. Bu doğrultuda, önemi giderek artan bağımsız denetim, iç denetim, iç kontrol ve adli muhasebe gibi uzmanlık alanlarında mesleği icra edecek kişilerin muhasebe ve denetim alanında yeterli bilgiyi kazandıracak mesleki eğitim almasının önemi büyüktür. Denetim uygulamalarının zorluğu dikkate alındığında, bu eğitimin lisans düzeyinde verilmeye başlanması daha faydalı olacaktır.

\section{Muhasebe Standartlart}

Muhasebe standartları uygulamasını düzenleyen 6102 sayılı TTK ile 2013 y1lı itibarıyla tüm işletmelere mali tablolarını düzenlerken Türkiye Muhasebe Standartları(TMS)/Türkiye Finansal Raporlama Standartlarına (TFRS) uyma zorunluluğu getirilmiş, 26.08.2014 tarihli Resmi Gazete'de yayımlanan Kamu Gözetimi Muhasebe ve Denetim Standartları Kurumu (KGK) kararı ile genel olarak kamu yararını ilgilendiren kuruluşların münferit ve konsolide finansal tablolarını hazırlanmasında TMS/TFRS uygulaması zorunlu kılınmıştır (www.resmigazete.gov.tr). KGK, standartları uygulaması gereken kuruluşların kapsamının her yıl genişletileceği ve belli süre içinde bütün büyük şirketlerin denetiminin TFRS'ler esas alınarak yapılacağını belirtmiştir (Şavlı, 2014'den aktaran: Gökçen vd.,2015:126). Bu konudaki son gelişmelerden biri de, 29 Temmuz 2017 tarihli ve 30138 sayılı mükerrer resmi gazetede yayınlanan "Büyük ve Orta Boy İşletmeler İçin Finansal Raporlama Standardı Hakkında Tebliğ" dir. Buna göre bağımsız denetime tabi olup, TFRS'yi uygulamayan işletmeler 01.01.2018 tarihinden itibaren BOBİ FRS (Büyük ve orta ölçekli işletmeler finansal raporlama standard1)'yi uygulayacaktır. BOBİ FRS'nin amacı, gerçeğe uygun, finansal bilgi ihtiyacına uygun ve karşılaştırılabilir finansal tablolar düzenlenmesini sağlamaktır (www.kgk.gov.tr). 
Farklı sektör ve büyüklükteki birçok işletmeyi ilgilendiren standartların etkin bir şekilde uygulanma sürecinde Türkiye'de karşılaşılan en başlıca sorun, anlaşılmasının zor olması, teknik ve karmaşık bilgiler içermesi ve farklı uygulamaları barındırıyor olmasıdır (Akdoğan, 2007:113). Bu noktada muhasebe meslek mensuplarının eğitilmesinin yanında, muhasebe eğitimi verilen programlarda standartlara ilişkin derslere yer verilmesi veya mevcut ders içeriklerinin TMS/TFRS'leri de içerecek şekilde yeniden tasarlanması gerekmektedir (Gökçen vd., 2015: 138).

Ayrıca, bu standartlarda yoğun bir şekilde kullanılan finans matematiği ve aktüeryal hesaplamaları da "Finans Matematiği Uzmanlığı" olarak ayrı bir uzmanlık alanı haline gelmiştir. Bu alandaki standartlara yön veren bugünkü değer kavram ve hesaplamaları ile uzun vadeli tahmin ve enterpolasyon yöntemlerinin gerekliliği çerçevesinde, matematik ve istatistiki bilgi birikimi gerektirmektedir (Sayar ve Karataş, 2017:22).

\section{Çevre Muhasebesi}

Küreselleşme olgusu işletmelere hızlı büyüme, yüksek kar elde etme gibi finansal hedeflerin yanısıra; dünyada yaşanan çevresel sorunlara daha duyarlı olma konusunda yeni sorumluluklar getirmekte ve bu doğrultuda gerçekleştirilen düzenlemelerde çevresel sorumluluk düzeylerinin artmasına neden olmaktadır. Kurumsal sosyal sorumluluk ve sürdürülebilirlik kapsamında değerlendirilen çevresel sorumluluklar, bir işletmenin ekonomik faaliyetlerinin ekosistemler üzerindeki etkisi ile ilgilidir. (Yıldız vd., 2016:256).

Kurumsal sürdürülebilirliği esas alan yeni paradigmaya göre, bir işletmenin genel performansının belirleyicileri yalnızca finansal sonuçlar değil, sosyal ve çevresel performans bütünüdür. $\mathrm{Bu}$ yaklaşım işletme faaliyetleriyle etkileşim halindeki tüm taraflara finansal bilgilerin yanında çevresel ve sosyal bilgilerin de raporlanmasını gerektirir (Önce vd., 2015: 235). Kurumsal sosyal sorumluluk ile birlikte hissedar ve diğer paydaş gruplarının artan bilgi talebi nedeniyle işletmelerde entegre raporlama, çevre muhasebesi, çevresel yönetim muhasebesi, çevresel maliyet, çevresel açıklama ve çevresel raporlamanın önemi giderek artmıştır (Yıldız vd., 2016:257).

\section{Değerleme}

Geçmişten günümüze muhasebe bilgi sisteminin temel uğraşı alanlarından biri olarak kabul edilen değerleme, aynı zamanda vergi unsurunun gerçekleşmesi ile önemli bir etkileşim içindedir. Değerleme olgusunun önemli amaçlarından birisi de şeffaflık ve hesap verebilirlik kavramlarının ön plana çıktığı TMS/TFRS kapsamında doğru finansal sunum ve ölçümleme süreci için önemli bir araç olarak kabul edilen gerçeğe uygun değerin tespitidir (Alpaslan, 2015:17). Muhasebe standartlarında, standartların temel değerleme kavramlarından biri olan "Gerçeğe Uygun Değer" kavramına geniş ölçüde değinilmekte, varlık ve borçların gerçeğe uygun bir şekilde ölçümlenmesi, değerlenmesi ve finansal tablolarda raporlanmasının, finansal tablo kullanıcılarının bilgi ihtiyacının en iyi şekilde karşılanmasına neden olacağ ifade edilmektedir (Alpaslan, 2015:28). Özellikle denetim uygulamalarının kalitesinin arttırılmasını teminen uluslararası standartların uygulamasının yaygınlaşması ile "varlık" ve "şirket" değerleme kavramlarının ön plana çıktığı görülmektedir. Gerçeğe uygun değer kavramına dayalı olarak finansal durum tablolarında değerleme yapma ihtiyacı, başta "Gayrimenkul Değerlemesi", "Patent Değerlemesi", "Marka Değerlemesi" ve "Şerefiye Değerlemesi" gibi kavram ve 
uygulamalarını özel bir uzmanlık haline getirmektedir (Sayar, 2010'dan aktaran: Sayar ve Karataş, 2017:18).

Bunların yanında, muhasebe mesleğinin türevi alt uzmanlık alanlarından olan kredi derecelendirme ve kurumsal yönetim derecelendirmesinden oluşan derecelendirme de yeni bir uzmanlık alanı olarak karşımıza çıkmaktadır. Şirketlerin veya şirketlerin ihraç etmiş oldukları finansal araçların yükümlülüklerini yerine getirebilme dereceleri ya da kalitelerinin belirli kriterlerle ortaya konularak sonuçta bir not verilmesi işlemi kredi derecelendirmenin konusudur. Kurumsal yönetim derecelendirmesi ise şirketlerin kurumsal yönetim ilkelerine uyum derecelerinin yine uygun bir derecelendirme metodolojisi ile notlandırılmasıdır (Sayar, 2010:31'den aktaran Sayar ve Karataş, 2017:19).

Her iki derecelendirme faaliyetinde de denetlenmiş finansal tablo verilerinden yararlanılmaktadır. Firmaların kredi yeterlilik kararında kullanılan finansal analiz kapsamında yapılan oran analizi, yüzde analizi, sektör analizi gibi yöntemlerde finansal tablolardaki kalemler ve bunlar arasındaki ilişki incelenmektedir. Benzer şekilde, kurumsal derecelendirme notunun tespitinde de, kurumsal yönetimin temel bileşenleri olan şeffaflık, hesap verebilirlik, eşitlik ve sorumluluk kavramlarının muhasebe bilgi sistemindeki ve finansal raporlardaki yerinin anlaşılması oldukça önemlidir.

Son olarak yaşanan krizler ve piyasalardaki dalgalanmalar riskin tanımlanması, ölçülmesi ve değerlendirilmesi çalışması olarak nitelendirilebilecek risk yönetim süreçlerinin gerekliliğini ortaya çıkarmıştır. Finans alanında yaşanan bu hızlı değişim, finans kurumlarının ve bireysel yatırımcıların risk yönetimi konusuna verdikleri önemi artırarak risk yönetim sistem ve tekniklerinin gelişimini hızlandırmıştır (Şahin ve Öncü, 2015:137).

$\mathrm{Bu}$ kapsamda, sürekli büyümeyi hedefleyen şirketlerin, kurumsal risk yönetimine öncelik verdiği görülmektedir. $\mathrm{Bu}$ şirketler, riskin etkisini azaltmak, şirket yönetimini sürprizlerden korumak için kontroller geliştirilmesi ve bu kontrollerin iş süreçlerine yerleştirilmesi üzerinde durmaktadırlar. Bu gereklilik ile iç denetimden; üst yönetime risklerin yönetimi ve iç kontrollerin etkinliği konularında yardımcı olması, kontrolleri sürekli izleyerek yeni kontroller önermesi beklenmektedir. Çünkü iç denetim; muhasebe ve mali raporlama sisteminin işlerliğ $i$, güvenilirliği, iç kontrollerin yerindeliği, risk yönetiminin etkinliğ $i$ konularında yönetim kuruluna gerekli güvenceyi sağlayabilecek etkili araçlardan biridir (http://www.denetimnet.net).

\section{Muhasebe Bilgi Sistemleri}

Bilgi teknolojilerindeki gelişmeler, elektronik ortamda muhasebe uygulamalarına geçişi sağlamış ve muhasebe uygulamalarında bilgisayarlar aracılığıyla bütünleşik sistemlere dayalı çeşitli yazılım programlarından yararlanma gereksinimi ortaya çıkarmıştır. Bilgisayar kullanımıyla; muhasebenin kayıt, raporlama ve analiz fonksiyonları çok kısa sürede gerçekleştirilebilmektedir. İşletmelerde; Kurumsal Kaynak Planlaması (KKP/ERP) uygulamalarına geçilerek, entegre yazılım programları aracılığıyla, tüm işletme fonksiyonlarının etkileşimi kolaylıkla sağlanabilmektedir. Bu bağlamda yeni sisteme geçiş sürecinde, elektronik ortamda muhasebe ve denetim uygulamalarına ve bütünleşik sistemlerle muhasebenin etkileşimi sonucu geliştirilmiş yazılım programlarına ve bu programları kullanabilen meslek elemanlarına yönelim artmıştır (Tektüfekçi, 2012:51). 
ERP yeterlilikleri günümüzde hemen hemen bütün alanlardaki iş ilanlarında yer alan temel bir özellik haline gelmiştir. Muhasebeden finansa, mühendislikten pazarlamaya ve insan kaynaklarından lojistik alanına kadar pek çok alana ait iş ilanlarında ERP uzmanlık bilgisi aranmaktadır (Kishalı ve Pehlivanl, 2011:179). Bu dikkatle, muhasebe meslek mensuplarının bilgi-teknolojileri ve iletişimi konusunda farkındalığı artırılmalı (Hacırüstemoğlu, 2009:24); muhasebe eğitiminde iyi derecede bilgisayar bilgisi ve entegre raporlama yapabilecek KKP mantığına sahip paket programları kullanabilme becerisi kazandırılmaya çalışılmalıdır.

$\mathrm{Bu}$ gereklilik denetim alanında kendini göstermektedir, zira sürekli denetim yaklaşımında denetçilerin bilgilerin elektronik olarak izlenmesi, bilgisayar yazılımları ve özel yazılım araçlarını kullanmaları hususunda özel beceriler geliştirmeleri gerekmektedir. Sürekli denetim, ileride gerçekleşmesi muhtemel hata ve hileleri, birtakım senaryolarla önceden belirleme ve olayın gerçekleşme anına çok yakın bir zamanda tespit edebilme imkanı sağlayan bir yaklaşımdır (Serçemeli ve Orhan, 2017:32).

\section{Stratejik Maliyet Yönetimi}

Günümüzde işletmeler muhasebecilerden, geleneksel olarak defter tutma ve maliyet hesaplama faaliyetlerin yanında, finansal analiz, bilanço okuma, karar verme, maliyet analizi ve yönetimi gibi stratejik öneme sahip konularda yönetim muhasebesinin gereklerini de yerine getirmelerini beklemektedirler.

Küresel rekabet, teknolojik yenilenme ve iş süreçlerindeki değişim, işletmelerin ürün, kalite, fonksiyonellik ve satış fiyatı üzerindeki hâkimiyetini ortadan kaldırmış, böylece geleneksel maliyet hesaplama yöntemleri günümüz işletmelerinin stratejik ve rekabet avantajı hedeflerine hizmet edemez hale gelmiştir. Bu yüzden stratejik maliyet yönetimi daha önceden olmadığ1 kadar önemli hale getirmiştir. Stratejik maliyet yönetimi (SMY), işletmelerin stratejik pozisyonlarını sürekli geliştirmek ve maliyetlerini düşürmek için maliyet yönetim tekniklerini uygulamasıdır. $\mathrm{Bu}$ çerçevede faaliyet tabanlı maliyetleme, yaşam boyu maliyetleme, hedef maliyetleme, kaizen maliyetleme ve kalite fonksiyon yayılımı gibi yöntemler stratejik maliyet yönetiminin değer zinciri analizi, stratejik konum analizi ve maliyet etkenleri analizlerinde yardımcı yöntemler olarak kullanılmaktadır (Yalçın, 2006:31).

Söz konusu alanlarda işletmeler eskisinden daha çok uzman danışmanlık hizmetlerine gereksinim duymaktadırlar. Bu gereksinim, muhasebe meslek mensuplarınca karşlanacak bir alt muhasebe uzmanlık alanı olarak değerlendirilmektedir (Sayar, 2010, 29'dan aktaran: Sayar ve Karataş, 2017:23).

Yukarıda sayılan uzmanlık alanlarının ortak yönü, hesaplama ve incelemelerinde muhasebe verilerinden hareket etmeleridir. Örneğin, bir şirket değerlemesinde uluslararası denetim standartlarına uygun olarak denetlenmiş ve uluslararası finansal raporlama standartlarına uygun olarak hazırlanmış finansal tablolar esas alınmaktadır. O halde bu yeni alanların tamamı muhasebe mesleğinin türevi olan yeni iş alanlarıdır. Bu alanlara meslek mensuplarının ilgi göstermesi, söz konusu alanlarda bilgi birikim ve donanımlarını artırmaya yönelik çaba ve çalışmalar içinde olmaları gerekmektedir (Sayar, 2010:30'dan aktaran Sayar ve Karataş, 2017:18). 
Araştırmada ders planları incelemesinde kullanılan her bir uzmanlık alanı için belirlenen ana başlıklar ve her ana başlık altında incelemeye tabi alt başlıklar aşağıdaki gibidir:

Tablo 1. Yeni Muhasebe Uzmanlık Alan Sınıflandırması

\begin{tabular}{|c|c|c|}
\hline Denetim & Muhasebe Standartları & Çevre Muhasebesi \\
\hline Bağımsız Denetim & Türkiye Muhasebe Standartları & Çevre Muhasebesi \\
\hline İç Denetim & Finansal Raporlama Standartları & Karbon Muhasebesi \\
\hline İç Kontrol & $\begin{array}{lll}\text { Türkiye Muhasebe } & \text { Ve } & \text { Finansal } \\
\text { Raporlama Standartları } & & \\
\end{array}$ & Çevre Maliyeti \\
\hline Hile Denetimi & $\begin{array}{lll}\text { Muhasebe } & \text { Standartları } & \text { Ve } \\
\text { Uygulamaları } & & \\
\end{array}$ & Sera Gazı Muhasebesi \\
\hline Adli Muhasebe & Uluslararası Muhasebe Standartları & Sorumluluk Muhasebesi \\
\hline Sistem Denetimi & Uluslararas1 Finansal Raporlama & Sosyal Sorumluluk Muhasebesi \\
\hline Süreç Denetimi & $\begin{array}{l}\text { Uluslararas1 Muhasebe Ve Finansal } \\
\text { Raporlama Standartlar1 }\end{array}$ & Entegre Raporlama \\
\hline Bilirkişilik & Finansal Raporlama & Çevresel Raporlama \\
\hline Yaratıc1 Muhasebe & Denetim Standartları & Karbon Bankacılığı \\
\hline Muhasebe Etiği & Finans Matematiği & Karbon Ticareti \\
\hline Muhasebe Mevzuatı & $\begin{array}{lll}\text { Türkiye } & \text { Finansal } & \text { Raporlama } \\
\text { Standartları } & & \\
\end{array}$ & \\
\hline Muhasebe Meslek Hukuku & $\begin{array}{lll}\begin{array}{l}\text { Uluslararas1 } \\
\text { standartlar1 }\end{array} & \text { finansal } & \text { raporlama } \\
\end{array}$ & \\
\hline Değerleme & Muhasebe Bilgi Sitemi & Stratejik Maliyet Yönetimi \\
\hline Varlık Değerleme-Derecelendirme & Bilgisayarl1 Muhasebe & Maliyet Yönetimi \\
\hline Şirket Değerleme-Derecelendirme & Muhasebe Bilgi Sistemleri & Maliyet Analizi \\
\hline Kurumsal Yönetim & Muhasebe Sistemi Tasarımı & Faaliyet Tabanlı Maliyetleme \\
\hline Vergi Muhasebesi & Muhasebe Organizasyonu & Hedef Maliyetleme \\
\hline Vergi Riski Değerleme & E-Ticaret Muhasebesi & Yaşam Boyu Maliyetleme \\
\hline Değerleme Uzmanlığı & Kurumsal Kaynak Planlaması & Kaizen Maliyetleme \\
\hline Gayrimenkul Değerleme & Muhasebe Bilişim Sistemi & Kalite Maliyetleri \\
\hline Patent Değerleme & Muhasebe Paket Programları & İşletme Bütçeleri \\
\hline Şerefiye Değerleme & Muhasebe Bilgi Teknolojileri & Lojistik Maliyetleme \\
\hline $\begin{array}{l}\text { Marka Değerleme } \\
\text { Marka Yönetimi }\end{array}$ & & Muhasebede Güncel Konular \\
\hline Kredi Derecelendirme & & İleri Maliyetleme \\
\hline Risk Yönetimi & & Muhasebede Özel Konular \\
\hline Türev Ürünler & & \\
\hline
\end{tabular}

\section{ARAŞTIRMA METODOLOJISİ}

\subsection{Araştırmanın Amacı ve Önemi}

Çalışmanın amacı, muhasebe mesleğindeki yeni uzmanlık alanlarına yönelik lisans düzeyinde verilen muhasebe eğitiminin mevcut durumunun tespitidir. $\mathrm{Bu}$ amaçla, Türkiye'deki devlet ve vakıf üniversitelerinin çeşitli fakülteleri bünyelerinde yer alan işletme bölümlerinin ders plan ve programları incelenmiş ve okutulan muhasebe dersleri güncel muhasebe uzmanlık alanları olarak tanımlanabilecek kategoriler çerçevesinde değerlendirilmiştir.

Çalışmanın, eğitimin paydaşları arasında yer alan öğrenci, öğretici ve yönetim açısından üç yönlü fayda sağlayacağı düşünülmektedir. İlk olarak öğrenciler, mezuniyet sonrası muhasebe alanında kendilerini bekleyen yeni çalışma alanları hakkında bilgi edinecek 
ve bu alanlara ilişkin derslere yönelebilecektir. İkinci olarak, muhasebe akademisyenleri muhasebe eğitimindeki yeni trendler doğrultusunda verilecek dersler için kendilerini yenilemeleri ve eğitmeleri gerekliliğinin farkına varabilecektir. Son olarak çalışmanın, ders plan ve programlarında yeterli ölçüde yer almayan yeni muhasebe uzmanlık alanlarına yönelik derslerin artırılması konusunda üniversitelerin ilgili birim yöneticileri için kaynak oluşturması beklenmektedir.

\subsection{Araştırmanın Kapsamı ve Yöntemi}

Araştırmanın kapsamını, devlet ve vakıf üniversitelerine bağlı fakültelerin Türkçe eğitim veren işletme bölümleri oluşturmaktadır. Türkiye'de 2017 yılı itibariyle, Yükseköğretim Kurulu'na bağlı 109'u devlet 76's1 vakıf olmak üzere toplam 185 üniversite bulunmaktadır. Ancak işletme bölümü olmayan, yabancı dilde eğitim veren veya yeni kurulan, aktif olarak eğitim vermeyen ya da internet üzerinden ders programlarına ulaşılamayan üniversiteler çalışmaya dahil edilemediğinden 111 adet üniversite (80'i devlet 31'i vakıf) çalışma kapsamına alınmıştır. Bu kapsamda söz konusu üniversitelerin İktisadi ve İdari Bilimler, İşletme, İktisat, Siyasal Bilgiler, Açık Öğretim, Sosyal ve Beşeri Bilimler, İnsan ve Toplum Bilimleri, İşletme ve Yönetim Bilimleri gibi çeşitli fakülte bünyelerinde yer alan 111 adet işletme bölümü eğitim programı incelenmiştir.

Araştırmada, tanımlayıcı araştırma modeli kullanılmış olup, gerekli veriler içerik analizi yöntemi ile elde edilmiştir. Bu noktada, öncelikle "Denetim, Muhasebe Standartları, Çevre Muhasebesi, Değerleme, Muhasebede Bilgi Sistemleri ve Stratejik Maliyet Yönetimi” ana başlıkları araştırma konusu olan yeni muhasebe uzmanlık alanları olarak kabul edilmiş, daha sonra bu altı grubun her birine ilişkin ders başlığı olarak kabul edilebilecek alt kategoriler belirlenmiştir. Bu noktada, Sayar ve Karataş (2017) tarafindan yapılan "Muhasebe ve Denetim Alanında Yaşanan Son Gelişmeler ile Muhasebe Mesleğinde Yeni Trendler" başlıklı çalışmadan yararlanılmıştır. Çalışma Tablo 1' de belirtildiği gibi işletme bölümlerinde, özellikle bu uzmanlık alanlarına ilişkin belirlenen ders başlıklarına yakın kelimeler içeren derslerin olup olmadığı ile sınırlandırılmış, içeriğinde kısmen sözkonusu uzmanlık alanlarının yer aldığı farklı ders başlıkları araştırma kapsamı dışında tutulmuştur.

Muhasebe derslerine ilişkin veriler, Yükseköğretim Kurulu'nun resmi web sayfası olan "www.yok.gov.tr" adresinden Türkiye'de eğitim veren devlet ve vakıf üniversitelerine bağlı fakültelerin işletme bölümlerinin internet sayfalarından ders programlarına ulaşılarak alınmıştır. Böylece yeni muhasebe uzmanlık alanlarına ilişkin derslerin bu üniversitelerde verilme düzeyi, ders saati ve seçimlik/zorunlu olma durumu da dikkate alınarak incelenmiştir.

\subsection{Araştırma Bulguları}

Bu kısımda, öncelikle ders programlarında yeni muhasebe uzmanlık alanlarına yönelik ders olan üniversite sayısına ilişkin dağılım hakkında bilgi verilecektir. İlgili bilgiler aşağıda Tablo 2' de gösterilmiştir. 
Tablo 2. Yeni Muhasebe Uzmanlık Alanlarına İlişkin Derslerin Üniversitelerde Verilme Durumu

\begin{tabular}{|l|l|l|l|l|l|l|}
\hline $\begin{array}{l}\text { Ders } \\
\text { Olma Durumu }\end{array}$ & Denetim & $\begin{array}{l}\text { Muhasebe } \\
\text { Standartları }\end{array}$ & $\begin{array}{l}\text { Çevre } \\
\text { Muhasebesi }\end{array}$ & Değerleme & $\begin{array}{l}\text { Muhasebe } \\
\text { Bilgi } \\
\text { Sistemleri }\end{array}$ & $\begin{array}{l}\text { Stratejik } \\
\text { Maliyet } \\
\text { Yönetimi }\end{array}$ \\
\hline $\begin{array}{l}\text { Ders olan üniversite } \\
\text { (Devlet) }\end{array}$ & 73 & 53 & 3 & 57 & 64 & 33 \\
\hline $\begin{array}{l}\text { Ders olan üniversite } \\
\text { (Vakıf) }\end{array}$ & 25 & 16 & - & 18 & 10 & 4 \\
\hline TOPLAM olmayan & 7 & 27 & 77 & 23 & 16 & 47 \\
\hline $\begin{array}{l}\text { Ders üniversite (Devlet) } \\
\text { ünan }\end{array}$ & 6 & 15 & 31 & 13 & 21 & 27 \\
\hline $\begin{array}{l}\text { Ders Olmayan } \\
\text { üniversite (Vakıf) }\end{array}$ & 13 & 42 & 108 & 36 & 37 & 74 \\
\hline Toplam & & & & & 75 & 37 \\
\hline
\end{tabular}

Tabloya göre, hem devlet hem de vakıf üniversitelerinde işletme bölüm programlarında en fazla yer bulan uzmanlık alanı denetimdir (98). Devlet üniversitelerinde bunu muhasebe bilgi sistemi (64) ve değerleme (57) uzmanlık alanları takip etmektedir. Vakıf Üniversitelerinde ise sıralama değerleme (18) ve muhasebe standartları (16) şeklindedir. Ders planlarında en az sayıda yer verilen uzmanlık alanı ise çevre muhasebesi (3) dir. Yine, tüm uzmanlık alanları için devlet üniversitelerinde ders verilme yüzdesinin vakıf üniversitelerine göre fazla olduğu görülmektedir. Bu noktada vakıf üniversitelerinin devlet üniversitelerine en çok yaklaştığı alan denetimdir (Vakıf:25/31=\%81- Devlet:73/80=\%91).

Genel olarak bakıldığında çevre muhasebesi (\%3) ve stratejik maliyet yönetimi (\%41) dışında her alanda devlet üniversitelerinin yarısından çoğunun ders programlarında ilgili uzmanlık alanına yönelik ders bulunmaktadır. Vakıf üniversitelerinde ise sadece denetim $(\% 81)$, değerleme $(\% 58)$ ve muhasebe standartları (\%52) alanlarında yarıdan fazla üniversitede uzmanlıklara yönelik dersler bulunmaktadır.

Aşağıdaki kısımda incelenen işletme bölüm ders programlarında sırayla denetim, muhasebe standartları, çevre muhasebesi, değerleme, muhasebede bilgi sistemi ve stratejik maliyet yönetimi uzmanlık alanlarına yönelik verilen derslere ilişkin bilgiler tablolar halinde yer almaktadır. Programlarda var olan dersler, dersin adı, kredisi ve seçimlik/zorunlu olma durumu açısından incelenmiştir.

Tablo 3. Denetim Uzmanlık Alanına İlişkin Dersler

\begin{tabular}{|l|l|l|l|l|l|l|}
\hline \multirow{2}{*}{ Ders İsimleri } & \multicolumn{2}{l|}{ Ders Sayısı } & \multicolumn{2}{l|}{ Ders Saati } \\
\cline { 2 - 8 } & Toplam & Z & S & $\mathbf{2}$ & $\mathbf{3}$ & $\mathbf{4}$ \\
\hline Adli Muhasebe & 2 & & 2 & 1 & 1 & \\
\hline Adli Muhasebe Ve Hile Denetimi & 1 & & 1 & & 1 & \\
\hline Denetim & 32 & 10 & 22 & 1 & 31 & \\
\hline Denetim Araştırmaları 1 & 2 & & 2 & 1 & 1 & \\
\hline Denetim Araştırmaları 2 & 2 & & 2 & 1 & 1 & \\
\hline Denetim Standartları & 1 & & 1 & & 1 & \\
\hline Denetim Teknikleri Ve Uygulamaları & 1 & & 1 & 1 & & \\
\hline Denetim Uygulamaları & 2 & & 2 & 1 & 1 & \\
\hline D1ş Denetim & 2 & & 2 & & 2 & \\
\hline
\end{tabular}




\begin{tabular}{|l|l|l|l|l|l|l|}
\hline Faaliyet Denetimi & 3 & & 3 & & 3 & \\
\hline Finansal Tablo Denetimi & 1 & & 1 & & 1 & \\
\hline İç Denetim & 9 & & 9 & 1 & 8 & \\
\hline İç Denetimin Temelleri & 1 & & 1 & 1 & & \\
\hline İç Kontrol & 1 & & 1 & & 1 & \\
\hline İç Kontrol Sistemleri 1 & 4 & & 4 & & 4 & \\
\hline İc Kontrol Sistemleri 2 & 1 & & 1 & & 1 & \\
\hline İç Kontrol Ve İç Denetimin Temelleri & 2 & & 2 & & 2 & \\
\hline İsletme Denetimi & 1 & 1 & & & 1 & \\
\hline İşletmelerde İç Denetim & 1 & & 1 & & 1 & \\
\hline Kamu Mali Denetimi & 1 & & 1 & & 1 & \\
\hline Mali Denetim & 3 & & 3 & & 3 & \\
\hline Meslek Mevzuatı & 1 & & 1 & & 1 & \\
\hline Muhasebe Denetimi & 66 & 30 & 36 & 7 & 58 & 1 \\
\hline Muhasebe Denetimi Uygulamaları & 1 & & 1 & & 1 & \\
\hline Muhasebe Denetimi Ve Mali Tablo Analizi & 1 & 1 & & & 1 & \\
\hline Muhasebe Etiği & 1 & & 1 & & 1 & \\
\hline Muhasebe Hukuk İlişkileri & 1 & & 1 & & 1 & \\
\hline Muhasebe Meslek Hukuku Ve Etik & 1 & & 1 & & 1 & \\
\hline Muhasebe Meslek Mevzuatı & 2 & & 2 & & 2 & \\
\hline Risk Odaklı İç Denetim & 1 & & 1 & & 1 & \\
\hline Uluslararası Denetim & 1 & & 1 & & 1 & \\
\hline Uluslararası Denetim Standartları & 1 & & 1 & & 1 & \\
\hline Uygunluk Denetimi & 3 & & 3 & & 3 & \\
\hline Toplam & 153 & 42 & 111 & 15 & 137 & 1 \\
\hline
\end{tabular}

Tablo incelendiğinde farklı fakültelerdeki işletme bölümlerinde denetim uzmanlık alanına ilişkin 34 farklı isim altında dersin verildiği ve en çok kullanılan ilk üç ders isminin "muhasebe denetimi"(66), "denetim(32)" ve "iç denetim(9)" olduğu görülmüştür. Yine tabloya göre, denetim alanına yönelik verilen derslerin 111'i seçimlik 42'si zorunlu olarak ders programlarında yer almaktadır. Ders saatleri açısından incelendiğinde ise 15 dersin 2 saat, 137 dersin 3 saat ve 1 dersin de 4 saat olarak verildiği tespit edilmiştir. Zorunluluğu en fazla olan ders "muhasebe denetimi" dersidir ve bu ders çoğunlukla 3 saat olarak işlenmektedir.

Tablo 4. Muhasebe Standartları Uzmanlık Alanına ilişkin Dersler

\begin{tabular}{|l|l|l|l|l|l|l|}
\hline \multirow{2}{*}{ Ders İsimleri } & \multicolumn{2}{l}{ Ders SayıS } & \multicolumn{2}{l|}{ Ders Saati } \\
\cline { 2 - 8 } & Toplam & Z & S & $\mathbf{2}$ & $\mathbf{3}$ & $\mathbf{4}$ \\
\hline Finans Matematiği & 18 & 5 & 13 & 3 & 15 & \\
\hline Finansal Matematik & 7 & 3 & 4 & 1 & 6 & \\
\hline Finansal Raporlama Standartları & 4 & & 4 & 1 & 3 & \\
\hline Kobi TFRS Uygulamaları & 1 & & 1 & & 1 & \\
\hline Muhasebe Standartları & 21 & 3 & 18 & 3 & 18 & \\
\hline Muhasebe Standartları 1 & 3 & - & 3 & & 3 & \\
\hline Muhasebe Standartları 2 & 3 & - & 3 & & 3 & \\
\hline Muhasebe Standartları -UFRS & 1 & & 1 & & 1 & \\
\hline Muhasebe Standartları Ve Uygulamaları & 1 & & 1 & & 1 & \\
\hline Muhasebe Ve Finansal Raporlama Standartları & 2 & 1 & 1 & 1 & 1 & \\
\hline Orta Düzey Muhasebe-UFRS Yaklaşımı 1 & 1 & & 1 & & 1 & \\
\hline Orta Düzey Muhasebe-UFRS Yaklaşımı 2 & 1 & & 1 & & 1 & \\
\hline TMS/TFRS Uygulamaları & 1 & & 1 & & 1 & \\
\hline Türkiye Finansal Raporlama Standartları & 2 & 1 & 1 & & 2 & \\
\hline Türkiye Muhasebe Standartları & 2 & & 2 & & 2 & \\
\hline Türkiye Muhasebe Standartları 1 & 1 & & 1 & & 1 & \\
\hline
\end{tabular}




\begin{tabular}{|c|c|c|c|c|c|}
\hline Türkiye Muhasebe Standartları 2 & 1 & & 1 & & 1 \\
\hline Türkiye Muhasebe Standartları Uygulamaları & 1 & & 1 & & 1 \\
\hline Türkiye Muhasebe/Finansal Raporlama Standartları & 1 & & 1 & & 1 \\
\hline Uluslararası Finansal Raporlama & 2 & & 2 & & 2 \\
\hline Uluslararası Finansal Raporlama 1 & 1 & & 1 & & 1 \\
\hline Uluslararası Finansal Raporlama 2 & 1 & & 1 & & 1 \\
\hline Uluslararas1 Finansal Raporlama Standartları & 9 & & 9 & & 9 \\
\hline Uluslararas1 Muhasebe & 4 & & 4 & & 4 \\
\hline Uluslararası Muhasebe Standartları & 7 & & 7 & & 7 \\
\hline Uluslararası Muhasebe Standartları 1 & 2 & 2 & & 1 & 1 \\
\hline Uluslararas1 Muhasebe Standartlar1 2 & 2 & 2 & & 1 & 1 \\
\hline $\begin{array}{lllll}\text { Uluslararas1 } & \text { Muhasebe } & \text { Ve } & \text { Finansal } & \text { Raporlama } \\
\text { Standartlar1 } & & & & \\
\end{array}$ & 1 & & 1 & & 1 \\
\hline Uluslararas1 Muhasebe Ve Raporlama Standartları & 1 & & 1 & & 1 \\
\hline Uluslararası Raporlama Standartları & 1 & & 1 & & 1 \\
\hline Toplam & 103 & 17 & 86 & 11 & 92 \\
\hline
\end{tabular}

Tablo 4' e göre farklı fakültelerde işletme bölümlerinde 30 farklı isimde muhasebe standartları uzmanlık alanına ilişkin ders verilmektedir ve en çok kullanılan ilk üç ders ismi "muhasebe standartları(21)", "finans matematiği(18)" ve "uluslararası finansal raporlama standartları(9)" dır. Yine tabloya göre, muhasebe standartları alanına yönelik verilen derslerin 86's1 seçimlik $17^{\prime}$ si zorunlu olarak ders programlarında yer almaktadır. Ders saatleri açısından incelendiğinde ise 11 dersin 2 saat, 92 dersin de 3 saat olarak verildiği tespit edilmiştir. Zorunluluğu en fazla olan ders "finans matematiği" dersidir ve bu ders çoğunlukla 3 saat olarak işlenmektedir.

Tablo 5. Çevre Muhasebesi Uzmanlık Alanına ilişkin Dersler

\begin{tabular}{|l|l|l|l|l|l|l|}
\hline Ders İsimleri & \multicolumn{3}{l|}{ Ders Sayısı } & \multicolumn{3}{l|}{ Ders Saati } \\
\cline { 2 - 8 } & Toplam & Z & S & $\mathbf{2}$ & $\mathbf{3}$ & $\mathbf{4}$ \\
\hline Çevre Muhasebesi & 5 & & 5 & 1 & 4 & \\
\hline
\end{tabular}

Çevre muhasebesi uzmanlık alanına ilişkin verilen tek ders yine aynı isimli olup, sadece Bartın, Sakarya ve Selçuk Üniversitesinde seçimlik düzeyde verilmektedir. Sakarya ve Bartın Üniversitelerinde bir ders, Selçuk Üniversitesinde ise üç farklı fakültenin işletme bölümünde birer ders olarak yer almaktadır.

Tablo 6. Değerleme Uzmanlık Alanına ilişkin Dersler

\begin{tabular}{|l|l|l|l|l|l|l|}
\hline \multirow{2}{*}{ Ders İsimleri } & \multicolumn{3}{l}{ Ders Sayısı } & \multicolumn{2}{l|}{ Ders Saati } \\
\cline { 2 - 7 } & Toplam & Z & S & $\mathbf{2}$ & $\mathbf{3}$ & $\mathbf{4}$ \\
\hline Bankacılıkta Risk Yönetimi & 1 & & 1 & & 1 & \\
\hline Değerleme & 1 & & 1 & & 1 & \\
\hline Değerleme Analizi & 1 & & 1 & & & 1 \\
\hline Değerleme Modelleri & 2 & & 2 & & 2 & \\
\hline Finansal Kurumlarda Risk Yönetimi & 1 & & 1 & & 1 & \\
\hline Finansal Risk Ve Türevleri & 1 & & 1 & & 1 & \\
\hline Finansal Risk Yönetimi & 3 & & 3 & & 3 & \\
\hline Finansal Risk Yönetimi Ve Araçları & 1 & & 1 & & 1 & \\
\hline Finansal Risk Yönetimi Ve Türev Piyasalar & 1 & & 1 & & 1 & \\
\hline Finansal Teknikler Ve Türev Araçlar & 2 & & 2 & & 2 & \\
\hline Finansal Türev Ürünlere Giriş & 1 & & 1 & & 1 & \\
\hline
\end{tabular}




\begin{tabular}{|c|c|c|c|c|c|c|}
\hline Finansal Türev Ürünler & 1 & & 1 & & 1 & \\
\hline Finansal Türevler & 3 & & 3 & & 3 & \\
\hline Finansal Türevler Ve Risk Yönetimi & 2 & & 2 & & 2 & \\
\hline Firma Değerlemesi & 5 & & 5 & & 5 & \\
\hline Gayrimenkul Değerleme Esasları & 1 & & 1 & & 1 & \\
\hline Gayrimenkul Değerlemesi & 1 & & 1 & & 1 & \\
\hline Gayrimenkul Finansmanı & 1 & & 1 & & 1 & \\
\hline Gayrimenkul Finansmanı Ve Değerlemesi & 2 & & 2 & & 2 & \\
\hline İşletmelerde Finansal Risk Yönetimi & 1 & & 1 & & 1 & \\
\hline Kredi Derecelendirme & 1 & & 1 & & 1 & \\
\hline Kriz Ve Risk Yönetimi & 1 & & 1 & & 1 & \\
\hline Kurumsal Yönetim & 14 & & 14 & & 14 & \\
\hline Kurumsal Yönetim Ve Sosyal Sorumluluk & 1 & & 1 & & 1 & \\
\hline Kurumsal Yönetişim & 4 & & 4 & 1 & 3 & \\
\hline Kurumsallaşma Ve Kurumsal Yönetim & 1 & & 1 & & 1 & \\
\hline Marka Yönetimi & 41 & 5 & 36 & 6 & 35 & \\
\hline Kurumsal Risk Yönetimi & 1 & & 1 & & 1 & \\
\hline Marka Ve Marka Stratejileri & 1 & & 1 & & 1 & \\
\hline Marka Yönetimi Araştırmaları 1 & 1 & & 1 & 1 & & \\
\hline Marka Yönetimi Araştırmaları 2 & 1 & & 1 & 1 & & \\
\hline Menkul Kiymetlerin Değerlendirilmesi & 1 & & 1 & & 1 & \\
\hline Muhasebede Vergi Uygulamaları & 1 & & 1 & & 1 & \\
\hline Risk Ve Portföy Yönetimi & 1 & & 1 & & 1 & \\
\hline Risk Ve Sigorta & 1 & & 1 & & 1 & \\
\hline Risk Yönetimi & 11 & 2 & 9 & & 11 & \\
\hline Risk Değerlemesi & 1 & & 1 & & 1 & \\
\hline Risk Yönetimi Araştırmaları 1 & 1 & & 1 & 1 & & \\
\hline Risk Yönetimi Araştırmaları 2 & 1 & & 1 & 1 & & \\
\hline Risk Yönetimi Ve Sigorta & 2 & & 2 & & 2 & \\
\hline Risk Yönetimi Ve Sigortacılık & 1 & & 1 & & 1 & \\
\hline Risk Yönetimi Ve Türev Ürünler & 2 & & 2 & & 2 & \\
\hline Sigortacılık Ve Risk Yönetimi & 1 & & 1 & & 1 & \\
\hline Stratejik Marka Yönetimi & 4 & & 4 & 1 & 3 & \\
\hline Şirket Değerlemesi & 2 & & 2 & & 2 & \\
\hline Türev Piyasalar & 2 & & 2 & & 2 & \\
\hline Türev Piyasalar Analizi & 1 & & 1 & & 1 & \\
\hline Türev Piyasalar Ve Araçlar & 1 & & 1 & & 1 & \\
\hline Türev Piyasalar Ve Risk Yönetimi & 1 & & 1 & & 1 & \\
\hline Türev Piyasalar Ve Enstrümanlar & 2 & & 2 & & 2 & \\
\hline Türev Piyasalar Ve Ürünleri & 1 & & 1 & & 1 & \\
\hline Türev Ürünler Ve Uluslararası Finansal Piyasalar & 1 & & 1 & & 1 & \\
\hline Türev Enstrümanlar Ve Risk & 1 & & 1 & & 1 & \\
\hline Uygulamalı Stratejik Marka Yönetimi & 1 & & 1 & & 1 & \\
\hline Ürün Ve Marka Yönetimi & 3 & & 3 & & 3 & \\
\hline Vadeli İşlemler Ve Opsiyon Sözleşmeleri & 1 & & 1 & 1 & & \\
\hline Varlık Değerleme & 1 & & 1 & & 1 & \\
\hline Vergi Hukuku Ve Muhasebe & 1 & & 1 & & 1 & \\
\hline Vergi Muhasebesi & 3 & & 3 & & 3 & \\
\hline Vergi Muhasebesi Ve Uygulamaları & 2 & & 2 & & 2 & \\
\hline Vergi Sitemi Ve Muhasebe & 1 & & 1 & & 1 & \\
\hline Vergi Uygulamaları Ve Muhasebesi & 1 & & 1 & & 1 & \\
\hline Yatırım Ve Risk Analizi & 1 & & 1 & & & 1 \\
\hline Toplam & 156 & 7 & 149 & 13 & 141 & 2 \\
\hline
\end{tabular}

Tablo 6 incelendiğinde değerleme uzmanlık alanına ilişkin 63 farklı isim altında dersin verildiği ve en çok kullanılan ilk üç ders isminin "marka yönetimi(41)", "kurumsal yönetim(14)" ve "risk yönetimi (11)" olduğu görülmüştür. Yine tabloya göre, denetim alanına yönelik verilen derslerin 149'u seçimlik 7'si zorunlu olarak ders programlarında yer 
almaktadır. Ders saatleri açısından incelendiğinde ise 13 dersin 2 saat, 141 dersin 3 saat ve 2 dersin de 4 saat olarak verildiği tespit edilmiştir. Zorunluluğu en fazla olan ders "marka yönetimi” dersidir ve bu ders çoğunlukla 3 saat olarak işlenmektedir.

Tablo 7. Muhasebe Bilgi Sistemi Uzmanlık Alanına ilişkin Dersler

\begin{tabular}{|c|c|c|c|c|c|c|}
\hline \multirow[t]{2}{*}{ Ders İsimleri } & \multicolumn{3}{|c|}{ Ders Sayısı } & \multicolumn{3}{|c|}{ Ders Saati } \\
\hline & Toplam & $\mathbf{Z}$ & $\mathbf{S}$ & 2 & 3 & 4 \\
\hline Bilgisayar Destekli Finansal Muhasebe Uygulamaları & 1 & & 1 & & 1 & \\
\hline Bilgisayar Destekli Maliyet Muhasebesi Uygulamaları & 1 & & 1 & & 1 & \\
\hline Bilgisayar Destekli Muhasebe & 3 & & 3 & & 3 & \\
\hline Bilgisayar Destekli Muhasebe Uygulamaları & 2 & & 2 & & 2 & \\
\hline Bilgisayarlı Muhasebe & 28 & 6 & 22 & 8 & 20 & \\
\hline Bilgisayarlı Muhasebe 1 & 3 & & 3 & & 3 & \\
\hline Bilgisayarl1 Muhasebe 2 & 3 & & 3 & & 3 & \\
\hline Bilgisayarlı Muhasebe Uygulamaları & 13 & 5 & 8 & 2 & 10 & 1 \\
\hline Bilgisayarlı Muhasebe Uygulamaları 1 & 3 & & 3 & 2 & 1 & \\
\hline Bilgisayarlı Muhasebe Uygulamaları 2 & 3 & & 3 & 2 & 1 & \\
\hline Bilgisayarlı Muhasebe Programları & 1 & 1 & & & 1 & \\
\hline Bilgisayar Uygulamalı Muhasebe & 1 & & 1 & & 1 & \\
\hline Bilgisayarlı Muhasebe Paket Programları & 1 & 1 & & & 1 & \\
\hline Bilgisayarlı Muhasebe Ve Paket Programlar & 1 & & 1 & & 1 & \\
\hline ERP Uygulamaları & 1 & & 1 & 1 & & \\
\hline Excel Ve Access İle Muhasebe Uygulamaları & 1 & & 1 & 1 & & \\
\hline İşletmelerde Muhasebe Organizasyonu & 1 & & 1 & & 1 & \\
\hline Kurumsal Kaynak Planlaması 1 & 1 & & 1 & 1 & & \\
\hline Kurumsal Kaynak Planlaması 2 & 1 & & 1 & 1 & & \\
\hline Kurumsal Kaynak Planlaması & 11 & 1 & 10 & & 11 & \\
\hline Kurumsal Kaynak Planlaması Ve Uygulamaları & 1 & & 1 & 1 & & \\
\hline Muhasebe Bilgi Sistemi & 12 & & 12 & 3 & 9 & \\
\hline Muhasebe Bilgi Sistemi Ve Organizasyonu & 1 & & 1 & & 1 & \\
\hline Muhasebe Bilgi Sistemleri & 8 & & 8 & & 8 & \\
\hline Muhasebe Bilgi Yönetimi & 1 & 1 & & & 1 & \\
\hline Muhasebe Bilişisim Sistemleri & 3 & 1 & 2 & 1 & 2 & \\
\hline Muhasebe Organizasyonu & 8 & & 8 & & 8 & \\
\hline Muhasebe Paket Programları & 3 & & 3 & & 3 & \\
\hline Muhasebe Sistemi Tasarımı & 1 & & 1 & & 1 & \\
\hline Muhasebe Sistemi Ve Organizasyonu & 2 & & 2 & & 2 & \\
\hline Muhasebede Bilgi Teknolojileri Kullanımı & 1 & 1 & & & 1 & \\
\hline Muhasebede Bilgisayar Kullanımı & 1 & & 1 & & 1 & \\
\hline Muhasebede Bilgisayar Uygulamaları & 1 & & 1 & & 1 & \\
\hline Sap İle Kurumsal Kaynak Planlama Sistemleri & 1 & & 1 & & 1 & \\
\hline Toplam & 124 & 17 & 107 & 23 & 100 & 1 \\
\hline
\end{tabular}

Tablo incelendiğinde muhasebe bilgi sistemi uzmanlık alanına ilişkin 34 farklı isim altında dersin verildiği ve en çok kullanılan ilk üç ders isminin "bilgisayarlı muhasebe (28)", "bilgisayarlı muhasebe uygulamaları(13)" ve "muhasebe bilgi sistemi (12)" olduğu görülmüş̧ür. Yine tabloya göre, bu alana yönelik verilen derslerin 107'si seçimlik 17'si zorunlu olarak ders programlarında yer almaktadır. Ders saatleri açısından incelendiğinde ise 23 dersin 2 saat, 100 dersin 3 saat ve 1 dersin de 4 saat olarak verildiği tespit edilmiştir. Zorunluluğu en fazla olan ders "bilgisayarlı muhasebe" dersidir ve bu ders çoğunlukla 3 saat olarak işlenmektedir. 
Tablo 8. Stratejik Maliyet Yönetimi Uzmanlık Alanına ilişkin Dersler

\begin{tabular}{|c|c|c|c|c|c|c|}
\hline \multirow[t]{2}{*}{ Ders İsimleri } & \multicolumn{3}{|c|}{ Ders Sayısı } & \multicolumn{3}{|c|}{ Ders Saati } \\
\hline & Toplam & $\mathbf{Z}$ & $\mathbf{S}$ & 2 & 3 & 4 \\
\hline Bütçeleme Ve Kar Planlaması & 1 & & 1 & & 1 & \\
\hline İleri Maliyet Muhasebesi & 2 & & 2 & & 2 & \\
\hline İleri Muhasebe & 1 & & 1 & & 1 & \\
\hline İleri Muhasebe Problemleri & 1 & & 1 & & 1 & \\
\hline İleri Muhasebe Uygulamaları & 1 & & 1 & & 1 & \\
\hline İleri Yönetim Muhasebesi & 1 & & 1 & & 1 & \\
\hline İşletme Bütçeleri & 8 & & 8 & 1 & 7 & \\
\hline İşletmelerde Bütçe Kontrol Sistemleri & 1 & & 1 & & 1 & \\
\hline İşletmelerde Bütçe Kontrol Teknikleri & 1 & & 1 & & 1 & \\
\hline Kalite Maliyetleri & 2 & & 2 & 2 & & \\
\hline Kalite Maliyetleri Ve Muhasebesi & 1 & & 1 & & 1 & \\
\hline Kalite Maliyetleri Ve Muhasebesi 1 & 2 & & 2 & & 2 & \\
\hline Kalite Maliyetleri Ve Muhasebesi 2 & 2 & & 2 & & 2 & \\
\hline Karar Vermede Muhasebe & 1 & & 1 & & 1 & \\
\hline Maliyet Analizi Ve Bütçeleme & 1 & & 1 & & 1 & \\
\hline Maliyet Muhasebesinde Çağdaş Yaklaşımlar & 1 & & 1 & & 1 & \\
\hline Maliyet Sistemleri & 1 & & 1 & & 1 & \\
\hline Maliyet Sistemleri Ve Maliyet Analizleri & 1 & & 1 & & 1 & \\
\hline Maliyet Yönetimi & 11 & 1 & 10 & 1 & 9 & 1 \\
\hline Maliyet Yönetimi 1 & 1 & & 1 & & 1 & \\
\hline Maliyet Yönetimi 2 & 1 & & 1 & & 1 & \\
\hline Muhasebede Güncel Konular & 4 & & 4 & & 4 & \\
\hline Muhasebe Ve Finansta İleri Konular & 1 & & 1 & & 1 & \\
\hline Muhasebede Güncel Konular 1 & 2 & & 2 & & 2 & \\
\hline Muhasebede Güncel Konular 1 & 2 & & 2 & & 2 & \\
\hline Muhasebede Seçilmiş Konular & 1 & & 1 & & 1 & \\
\hline Stratejik Maliyet Yönetimi & 1 & & 1 & & 1 & \\
\hline Tedarik Zinciri Maliyet Analizi & 1 & & 1 & & 1 & \\
\hline Yönetim Muhasebesinde Güncel Konular 1 & 1 & & 1 & & 1 & \\
\hline Yönetim Muhasebesinde Güncel Konular 2 & 1 & & 1 & & 1 & \\
\hline Toplam & 56 & 1 & 55 & 4 & 51 & 1 \\
\hline
\end{tabular}

Tablo incelendiğinde farklı fakültelerdeki işletme bölümlerinde stratejik maliyet yönetimi uzmanlık alanına ilişkin 30 farklı isim altında dersin verildiği ve en çok kullanılan ilk üç ders isminin "maliyet yönetimi(11)", "işletme bütçeleri(8)" ve "muhasebede güncel konular(4)" olduğu görülmüştür. Yine tabloya göre, bu alana yönelik verilen derslerin 55'i seçimlik 1'i zorunlu olarak ders programlarında yer almaktadır. Ders saatleri açısından incelendiğinde ise 4 dersin 2 saat, 51 dersin 3 saat ve 1 dersin de 4 saat olarak verildiği tespit edilmiştir.

Tablolar incelendiğinde, genel olarak ders programlarında toplam ders sayısı açısından en fazla yer bulan uzmanlık alanının "Değerleme" olduğu ve genelde ilgili derslerin seçimlik düzeyde ve 3 saat olarak verildiği görülmüştür. En az ders sayısı ise "Çevre Muhasebesi" alanına aittir. Bu durum aşağıda tablo 9' da karşılaştırmalı olarak gösterilmiştir. 
Tablo 9. Yeni Muhasebe Uzmanlık Alanlarına İlişkin Toplam Ders Sayıları

\begin{tabular}{|l|l|l|l|l|l|l|}
\hline & Denetim & $\begin{array}{l}\text { Muhasebe } \\
\text { Standartları }\end{array}$ & $\begin{array}{l}\text { Çevre } \\
\text { Muhasebesi }\end{array}$ & Değerleme & $\begin{array}{l}\text { Muhasebe } \\
\text { Bilgi } \\
\text { Sistemleri }\end{array}$ & $\begin{array}{l}\text { Stratejik } \\
\text { Maliyet } \\
\text { Yönetimi }\end{array}$ \\
\hline $\begin{array}{l}\text { Toplam Ders } \\
\text { Sayısı }\end{array}$ & 153 & 103 & 5 & 156 & 124 & 56 \\
\hline $\begin{array}{l}\text { Zorunlu Ders } \\
\text { Sayısı }\end{array}$ & 42 & 17 & - & 7 & 17 & 1 \\
\hline
\end{tabular}

Bazı üniversitelerde farklı fakültelerde birden çok işletme bölümü olabildiği ve bu bölümlerde uzmanlık alanlarının her birine ilişkin birden fazla sayıda ders verilebildiği için incelenen işletme bölümü program sayısı 111 olmasına karşılık tablodaki bazı ders sayıları daha fazladir.

Son olarak, aşağıdaki bölümde işletme bölüm ders programlarında yeni muhasebe uzmanlık alanlarına yönelik ders olan devlet ve vakıf üniversitelerine ilişkin tablolar yer almaktadır. Bu tablolarda, mükerrer uygulamadan kaçınmak için, aynı üniversitenin farklı fakültelerindeki işletme bölümlerinde ilgili derslere yer verilmesi durumunda ders yoğunluğunun en fazla olduğu tek fakülte esas alınmıştır.

Tablo 10. Yeni Muhasebe Uzmanlık Alanlarına İlişkin Ders Veren Devlet Üniversiteleri

\begin{tabular}{|c|c|c|c|c|c|c|c|}
\hline Üniversite adı & : & 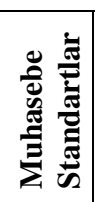 & 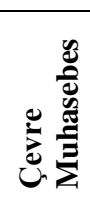 & 这 & 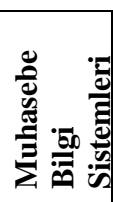 & 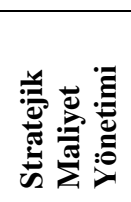 & $\frac{\Xi}{\tilde{\sigma}}$ \\
\hline Abant İzzet Baysal Üniversitesi & 1 & 1 & - & 1 & 1 & 4 & 8 \\
\hline Adıyaman Üniversitesi & 1 & 2 & - & - & 2 & - & 5 \\
\hline Adnan Menderes Üniversitesi & - & - & - & 1 & - & 2 & 3 \\
\hline Afyon Kocatepe Üniversitesi & 2 & - & - & 1 & 2 & - & 5 \\
\hline Ağrı İbrahim Çeçen Üniversitesi & 1 & - & - & - & - & - & 1 \\
\hline Ahi Evran Üniversitesi & 1 & - & - & 1 & - & - & 2 \\
\hline Akdeniz Üniversitesi & 1 & 2 & - & - & 2 & 2 & 7 \\
\hline Aksaray Üniversitesi & 1 & 1 & - & 1 & 1 & - & 4 \\
\hline Alanya Alaaddin Keykubat Üniversitesi & 1 & 1 & - & 2 & 1 & - & 5 \\
\hline Anadolu Üniversitesi & 2 & 1 & - & 1 & 3 & 1 & 8 \\
\hline Artvin Çoruh Üniversitesi & 1 & 2 & - & 2 & 2 & 1 & 8 \\
\hline Balıkesir Üniversitesi & 1 & 1 & - & 3 & 1 & 1 & 7 \\
\hline Bandırma Onyedi Eylül Üniversitesi & 2 & 3 & - & 4 & 4 & - & 13 \\
\hline Bartın Üniversitesi & 2 & 2 & 1 & 1 & 2 & 1 & 9 \\
\hline Batman Üniversitesi & 1 & 1 & - & - & - & 1 & 3 \\
\hline Bayburt Üniversitesi & 1 & 2 & - & - & 2 & 1 & 6 \\
\hline Bilecik Şeyh Edebali Üniversitesi & 2 & 2 & - & 3 & 3 & 1 & 11 \\
\hline Bingöl Üniversitesi & 1 & - & - & 1 & - & - & 2 \\
\hline Bülent Ecevit Üniversitesi & 1 & 1 & - & 3 & 1 & - & 6 \\
\hline Bozok Üniversitesi & 1 & 1 & - & 1 & 1 & - & 4 \\
\hline Cumhuriyet Üniversitesi & 1 & - & - & - & 1 & - & 2 \\
\hline Çanakkale Onsekiz Mart Üniversitesi & 2 & 1 & - & 1 & 3 & 1 & 8 \\
\hline Çankırı Karatekin Üniversitesi & 1 & 2 & - & 3 & 2 & - & 8 \\
\hline Dicle Üniversitesi & 1 & - & - & - & 1 & - & 2 \\
\hline Dokuz Eylül Üniversitesi & 2 & 2 & - & 5 & 2 & 2 & 13 \\
\hline Dumlupınar Üniversitesi & 1 & 1 & - & - & - & - & 2 \\
\hline Erciyes Üniversitesi & 1 & - & - & 2 & 2 & - & 5 \\
\hline Erzincan Üniversitesi & 2 & - & - & - & 1 & - & 3 \\
\hline Erzurum Teknik Üniversitesi & 1 & 1 & - & 3 & - & - & 5 \\
\hline
\end{tabular}




\begin{tabular}{|c|c|c|c|c|c|c|c|}
\hline Eskişehir Osmangazi Üniversitesi & 5 & - & - & 2 & 1 & 2 & 10 \\
\hline Firat Üniversitesi & 1 & 1 & - & 1 & - & - & 3 \\
\hline Galatasaray Üniversitesi & 3 & 1 & - & - & - & 1 & 5 \\
\hline Gazi Üniversitesi & 2 & 1 & - & 4 & - & - & 7 \\
\hline Gaziantep Üniversitesi & 1 & 1 & - & 3 & 2 & 1 & 8 \\
\hline Gaziosmanpaşa Üniversitesi & 1 & 1 & - & - & 3 & - & 5 \\
\hline Giresun Üniversitesi & 1 & - & -- & 1 & 2 & - & 4 \\
\hline Gümüşhane Üniversitesi & 1 & 1 & - & 2 & 1 & - & 5 \\
\hline Harran Üniversitesi & 1 & 2 & - & - & 1 & - & 4 \\
\hline Hitit Üniversitesi & 1 & 1 & - & - & - & - & 2 \\
\hline Iğdır Üniversitesi & - & - & - & 2 & 1 & - & 3 \\
\hline İnönü Üniversitesi & 1 & 2 & - & 1 & 1 & 1 & 6 \\
\hline İstanbul Medeniyet Üniversitesi & 2 & 1 & - & 3 & 2 & 1 & 9 \\
\hline İstanbul Ticaret Üniversitesi & - & - & - & 1 & - & - & 1 \\
\hline İstanbul Üniversitesi & 4 & 1 & - & 4 & 3 & - & 12 \\
\hline İzmir Katip Çelebi Üniversitesi & 1 & - & - & - & 1 & - & 2 \\
\hline Sütçü İmam Üniversitesi & 1 & 1 & - & 1 & 1 & - & 4 \\
\hline Karabük Üniversitesi & 1 & - & - & 1 & 1 & 1 & 4 \\
\hline Karadeniz Teknik Üniversitesi & 1 & 1 & - & - & 1 & - & 3 \\
\hline Karamanoğlu Mehmetbey Üniversitesi & 1 & 1 & - & 1 & 1 & 1 & 5 \\
\hline Kastamonu Üniversitesi & 1 & - & - & 4 & 1 & - & 6 \\
\hline Kırklareli Üniversitesi & 1 & 3 & - & - & - & - & 4 \\
\hline Kırıkkale Üniversitesi & 1 & 2 & - & - & 1 & - & 4 \\
\hline Kilis Üniversitesi & 1 & - & - & - & - & - & 1 \\
\hline Kocaeli Üniversitesi & 1 & 2 & - & 2 & 3 & 1 & 9 \\
\hline Manisa Celal Bayar Üniversitesi & 1 & 3 & - & 1 & 2 & 1 & 8 \\
\hline Mardin Artuklu Üniversitesi & 1 & 1 & - & 1 & 2 & 1 & 6 \\
\hline Marmara Üniversitesi & 5 & 1 & - & 1 & 2 & - & 9 \\
\hline Maltepe Üniversitesi & - & - & - & 2 & - & - & 2 \\
\hline Mehmet Akif Ersoy Üniversitesi & 1 & 1 & - & 1 & 1 & - & 4 \\
\hline Mersin Üniversitesi & 1 & - & - & - & 1 & - & 2 \\
\hline Muğla Sitkı Koçman Üniversitesi & 1 & 1 & - & 2 & - & - & 4 \\
\hline Tunceli Munzur Üniversitesi & 1 & 1 & - & 1 & 1 & - & 4 \\
\hline Hatay Mustafa Kemal Üniversitesi & 1 & - & - & 1 & 1 & - & 3 \\
\hline Namık Kemal Üniversitesi & 1 & - & - & - & 1 & - & 2 \\
\hline Necmettin Erbakan Üniversitesi & - & 1 & - & - & 2 & - & 3 \\
\hline Nevşehir Hacı Bektaş Üniversitesi & 1 & - & - & - & 1 & - & 2 \\
\hline Niğde Ömer Halisdemir Üniversitesi & $\frac{1}{1}$ & - & - & 2 & 1 & 1 & 5 \\
\hline Ondokuz Mayıs Üniversitesi & 1 & 1 & - & 1 & 1 & 1 & 5 \\
\hline Ordu Üniversitesi & 1 & 3 & - & 3 & 2 & - & 9 \\
\hline Osmaniye Korkut Ata Üniversitesi & - & 1 & - & 2 & 1 & - & 4 \\
\hline Pamukkale Üniversitesi & 2 & - & - & 3 & 3 & 1 & 9 \\
\hline Sakarya Üniversitesi & 3 & - & 1 & 1 & 3 & 2 & 10 \\
\hline Selçuk Üniversitesi & 5 & 2 & 1 & 2 & 3 & 4 & 17 \\
\hline Siirt Üniversitesi & 1 & - & - & - & - & 1 & 2 \\
\hline Şırnak Üniversitesi & 1 & 1 & - & 1 & 1 & - & 4 \\
\hline Trakya Üniversitesi & 1 & 1 & - & 2 & 3 & - & 7 \\
\hline Uludağ Üniversitesi & 3 & 2 & - & 4 & 3 & - & 12 \\
\hline Uşak Üniversitesi & 4 & - & - & 7 & 2 & - & 13 \\
\hline Yalova Üniversitesi & - & 2 & - & 1 & - & - & 3 \\
\hline Yıldız Teknik Üniversitesi & 2 & 2 & - & 3 & 2 & - & 9 \\
\hline Toplam & 109 & 77 & 3 & 115 & 106 & 39 & \\
\hline
\end{tabular}

Tablo 10 incelendiğinde, yeni muhasebe uzmanlık alanlarına ilişkin en fazla sayıda ders veren ilk üç devlet üniversitesi, Selçuk (17), Dokuz Eylül (13), Uşak (13), Bandırma Onyedi Eylül(13) ve İstanbul (12) Üniversiteleridir. Uzmanlık alanları tek tek değerlendirildiğinde ise, en fazla ders sayısı, denetim alanında, Marmara ve Selçuk 
Üniversiteleri (5); muhasebe standartları alanında Bandırma Onyedi Eylül, Ordu, Manisa Celal Bayar ve Kırklareli Üniversiteleri (3); değerleme alanında Uşak Üniversitesi(7); muhasebe bilgi sitemleri için Bandırma Onyedi Eylül (4) ve stratejik maliyet yönetimi içinse Abant İzzet Baysal ve Selçuk Üniversitelerine aittir.

Tablo 11. Yeni Muhasebe Uzmanlık Alanlarına İlişkin Ders Veren Vakıf Üniversiteleri

\begin{tabular}{|c|c|c|c|c|c|c|c|}
\hline Üniversite adı & 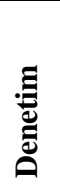 & 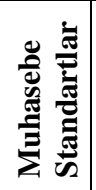 & 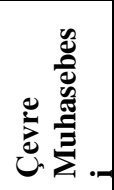 & 苞 & 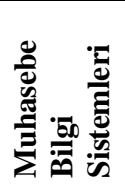 & 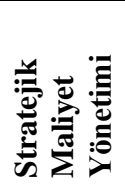 & $\frac{\text { है }}{\text { है }}$ \\
\hline Altınbaş Üniversitesi & 1 & - & - & 3 & - & 2 & 6 \\
\hline Atılım Üniversitesi & - & 1 & - & - & - & - & 1 \\
\hline Avrasya Üniversitesi & - & - & - & 1 & 1 & - & 2 \\
\hline Bahçeşehir Üniversitesi & 2 & - & - & 1 & - & - & 3 \\
\hline Başkent Üniversitesi & 1 & 1 & - & 2 & - & 1 & 5 \\
\hline Beykent Üniversitesi & - & - & - & - & 1 & - & 1 \\
\hline Çankaya Üniversitesi & 1 & 1 & - & 1 & - & - & 3 \\
\hline Doğuş Üniversitesi & 1 & - & - & 2 & - & - & 3 \\
\hline Haliç Üniversitesi & 1 & 1 & - & 1 & - & - & 3 \\
\hline Hasan Kalyoncu Üniversitesi & 1 & - & - & - & - & - & 1 \\
\hline Iş1k Üniversitesi & 1 & - & - & - & - & - & 1 \\
\hline İbni Haldun Üniversitesi & 1 & 1 & - & 3 & - & - & 5 \\
\hline İstanbul Arel Üniversitesi & - & 1 & - & - & - & 1 & 2 \\
\hline İstanbul Gelişim Üniversitesi & 1 & 3 & - & 3 & - & - & 7 \\
\hline İstanbul Kent Üniversitesi & 1 & 1 & - & - & 1 & - & 3 \\
\hline İstanbul Kültür Üniversitesi & 1 & 1 & - & - & 2 & - & 4 \\
\hline İstanbul Sabahattin Zaim Üniversitesi & 1 & - & - & - & - & - & 1 \\
\hline Yeniyüzyıl Üniversitesi & 1 & 1 & - & - & - & - & 2 \\
\hline İzmir Ekonomi Üniversitesi & 2 & - & - & 1 & - & - & 3 \\
\hline Koç Üniversitesi & 1 & - & - & - & - & - & 1 \\
\hline KTO Karatay Üniversitesi & 2 & 2 & - & 2 & - & 1 & 7 \\
\hline Nişantaş1 Üniversitesi & - & 1 & - & 3 & 1 & - & 6 \\
\hline Nuh Naci Yazgan Üniversitesi & 1 & - & - & - & 1 & - & 2 \\
\hline Okan Üniversitesi & 1 & - & - & - & - & - & 1 \\
\hline Özyeğin Üniversitesi & 1 & - & - & 1 & 1 & - & 3 \\
\hline TOBB Üniversitesi & 1 & - & - & 2 & 1 & - & 4 \\
\hline THY Üniversitesi & 1 & 1 & - & - & - & - & 2 \\
\hline Türk Alman Üniversitesi & - & 2 & - & 1 & - & - & 3 \\
\hline Ufuk Üniversitesi & 1 & - & - & 1 & - & - & 2 \\
\hline Yaşar Üniversitesi & 2 & 2 & - & 4 & 2 & - & 10 \\
\hline Yeditepe Üniversitesi & 2 & 1 & - & 3 & 2 & - & 8 \\
\hline Toplam & 30 & 21 & - & 35 & 13 & 5 & \\
\hline
\end{tabular}

Tablo 11'e göre, yeni muhasebe uzmanlık alanlarına ilişkin en fazla sayıda ders veren ilk üç vakıf üniversitesi, Yeditepe(8), İstanbul Gelişim(7), KTO Karatay(7), Altınbaş(6), ve Nişantaşı(6) üniversiteleridir. Tablo 12' de uzmanlık alanlarına göre ders sayıları devlet ve vakıf üniversiteleri açsından karşılaştırılmıştır. 
Tablo 12. Yeni Muhasebe Uzmanlık Alanlarına İlişkin Ders Sayıları

\begin{tabular}{|l|l|l|l|l|l|l|}
\hline & Denetim & $\begin{array}{l}\text { Muhasebe } \\
\text { Standartlar1 }\end{array}$ & $\begin{array}{l}\text { Çevre } \\
\text { Muhasebesi }\end{array}$ & Değerleme & $\begin{array}{l}\text { Muhasebe Bilgi } \\
\text { Sistemi }\end{array}$ & $\begin{array}{l}\text { Stratejik Maliyet } \\
\text { Yönetimi }\end{array}$ \\
\hline $\begin{array}{l}\text { Devlet } \\
\text { Universitelerindeki } \\
\text { Ders Sayls1 }\end{array}$ & 109 & 77 & 3 & 115 & 106 & 39 \\
\hline $\begin{array}{l}\text { Vak1f } \\
\begin{array}{l}\text { Universitelerindeki } \\
\text { Ders Sayls1 }\end{array}\end{array}$ & 30 & 21 & - & 35 & 13 & 5 \\
\hline
\end{tabular}

Tabloya göre, hem devlet hem de vakıf üniversitelerinde işletme bölüm programlarında ders sayısı açısından en fazla dersi barındıran ilk iki uzmanlık alanı "Değerleme" ve "Denetim" dir. Devlet üniversitelerinde üçüncü sirada muhasebe bilgi sistemi varken vakıf üniversitelerinde muhasebe standartları yer almaktadır.

\section{SONUÇ VE ÖNERILER}

$\mathrm{Bu}$ çalışmada, Türkiye'deki devlet ve vakıf üniversitelerinin ilgili fakültelerindeki kapsama alınan işletme bölümlerinde "denetim, muhasebe standartları, çevre muhasebesi, değerleme, muhasebede bilgi sistemleri ve stratejik maliyet yönetimi" uzmanlık muhasebe alanlarına yönelik eğitimin hangi düzeyde verildiğine ilişkin bir araştırma yapılmıştır.

İncelenen programlarda belirlenen uzmanlık alanlarına ilişkin çok farklı isimler altında ders verildiği, en çok kullanılan ders isimlerinin, sırayla "muhasebe denetimi, muhasebe standartları, çevre muhasebesi, marka yönetimi, bilgisayarlı muhasebe ve maliyet yönetimi "olduğu görülmüştür. Ayrıca, her bir uzmanlık alanı için belirlenen derslerin büyük çoğunluğu seçimliktir ve genellikle haftada 3 saat olarak yedinci ve sekizinci dönem programlarında yer almaktadırlar. Bologna sürecinin eğitimde getirdiği yenilikler ve işletme bölüm müfredatları içinde muhasebe derslerinin payı düşünüldüğünde bu tarz uzmanlık derslerinin seçimlik olması normal karşılanmalıdır.

Araştırmaya göre, hem devlet hem de vakıf üniversitelerinde işletme bölüm programlarında yeni uzmanlık alanları içinde en fazla sayıda yer alan uzmanlık alanı "denetim" dir. Buna karşılık her bir uzmanlık alanı için verilen toplam ders sayıları açısından yapılan incelemede, en fazla dersin verildiği alan "değerleme" olmuştur. $\mathrm{Bu}$ sonuçta değerleme uzmanlık alanı için belirlenen alt kategorilerin denetim alanına göre daha geniş bir yelpaze içeriyor olmasının etkisi olduğu düşünülmektedir. Ders planlarında en az sayıda yer verilen uzmanlık alanı ise yalnızca üç devlet üniversitesinde verilen çevre muhasebesidir. Yine, tüm uzmanlık alanları için devlet üniversitelerinde ders verilme yüzdesinin vakıf üniversitelerine göre fazla olduğu görülmektedir. Bu noktada vakıf üniversitelerinin devlet üniversitelerine en çok yaklaştığı alan denetimdir.

Genel olarak bakıldığında çevre muhasebesi ve stratejik maliyet yönetimi dışında her alanda devlet üniversitelerinin yarısından çoğunun ders programlarında ilgili uzmanlık alanına yönelik ders bulunmaktadır. Vakıf üniversiteleri açısından ise sadece denetim, değerleme ve muhasebe standartları alanlarında yarıdan fazla üniversitede uzmanlıklara yönelik dersler bulunmaktadır. Ders planlarında yeni muhasebe uzmanlık alanlarına ilişkin en 
fazla sayıda derse yer veren devlet ve vakıf üniversiteleri ise, sırayla, Selçuk ve Yeditepe Üniversiteleri olmuştur.

Araştırma sonuçları, henüz yeterli seviyede olmasa da lisans programları kapsamında bu yeni uzmanlık alanlarını içerecek şekilde dersler olduğunu göstermektedir. Tüm bu veriler 1şığında, Türkiye'deki lisans düzeyinde muhasebe eğitiminin, muhasebe alanındaki gelişmeler sonucu önemi artan muhasebe uzmanlık alanlarının gerektirdiği bilgi birikiminin sağlanması yönünde olumlu bir gelişme süreci içinde olduğu söylenebilir. Bununla birlikte kurumsal yönetim ve kurumsal sosyal sorumluluğun artan önemi dikkate alındığında ders planlarında yeterli seviyede yer almayan uzmanlık alanlarına, özellikle çevre muhasebesi ve stratejik maliyet yönetimi alanlarına yönelik derslerin üniversite müfredatlarına eklenmesi ve mevcut ders içeriklerinin güncellenmesi fayda sağlayacaktır.

Bundan sonraki araştırmalarda lisans bölümü dışında yüksek lisans ve doktora ders programları sözkonusu uzmanlıklar çerçevesinde araştırılabilir. İş dünyasından kişiler ve muhasebe meslek mensupları ile görüşülerek ilgili sektörlerin uzmanlıklara ilişkin muhasebe eğitiminden ne beklediği tespit edilebilir. Araştırmaya ders içerikleri dahil edilerek kapsam genişletilebilir.

\section{KAYNAKLAR}

Akdoğan, Nalan (2007), "Türkiye Muhasebe/Finansal Raporlama Standartlarının Uygulanma Süreci: Sorunlar ve Çözüm Önerileri”, Mali Çözüm Dergisi, Sayı:80, ss.101-117.

Alpaslan, Halil İbrahim (2015), “TMS/TFRS Kapsamında Gayrimenkul Değerleme Ve Gerçeğe Uygun Değerin Tespitinde Emsal Karşılaştırma ve Gelir İndirgeme Yöntemleri Üzerine Bir Uygulama”, Nevşehir Hacı Bektaş Veli Üniversitesi Sosyal Bilimler Enstitüsü Dergisi, 4, ss. 17-35.

Gökçen, Gürbüz- Ataman, Başak-Cebeci, Yasin-Cavlak, Hakan (2015), “Türkiye'deki Devlet Üniversitelerinin Lisans Programlarındaki Muhasebe Standartları Eğitimi Üzerine Bir Araştırma”, Marmara Üniversitesi Öneri Dergisi, Cilt:11, Sayı:44, Temmuz, ss. 121145 .

Hacırüstemoğlu, Rüstem (2009), "Muhasebede Uzmanlaşma” Mali Çözüm Dergisi, Sayı 93, ss.17-27.

http://www.denetimnet.net/UserFiles/Documents/2011/Kurumsal_Risk_Yonetimi_ve_ic_Den etim.pdf.

Kavut, Lerzan- Adiloğlu, Burcu (2016), “Türkiye'de Bağımsız Denetimin Gelişimi: Dünden Bugüne", Seçmeler, İstanbul Üniversitesi İşletme Fakültesi Muhasebe Enstitüsü, İstanbul, ss.35-61.

Kishal1, Yunus-Pehlivanl1, Davut (2011), "ERP Temelli Muhasebe Derslerinde Karşılaşılabilecek Problemler ve Uygulama Önerileri”, XXX. Türkiye Muhasebe Eğitimi Sempozyumu: Sektörlerin Muhasebe Eğitiminden Beklentileri Bildiri Kitabı, 
Gazi Üniversitesi İktisadi ve İdari Bilimler Fakültesi İşletme Bölümü, Side-Antalya, ss.171-180.

Önce, Saime-Onay-Ahmet-Yeşilçelebi, Gül (2015), "Kurumsal Sürdürülebilirlik Raporlaması ve Türkiye'deki Durum", Journal of Economics, Finance and Accounting, Vol. 2, No. 2, ss. 230-252.

Sayar, A.R.Zafer (2010), "Muhasebe Mesleğinde Açılım ve Yeni Ufuklar: Uzmanlaşma (I)”, ASMMMO Bülten Dergisi, 20, 190, ss. 29-31.

Sayar, A.R. Zafer-Karataş, Muharrem (2017), "Muhasebe ve Denetim Alanında Yaşanan Son Gelişmeler İle Muhasebe Mesleğinde Yeni Trendler", Mali Çözüm Dergisi, OcakŞubat, ss.13-28.

Serçemeli, Murat-Orhan, M.Suphi (2017), "Sürekli Denetim ve Denetimin Geleceğine Bakış Üzerine BIST-100 Şirketlerinde Bir Araştırma”, Sayıştay Dergisi, Sayı: 101, Nisan Haziran, ss.31-50.

Şahin, Özkan-Öncü, Mehmet Akif (2015), "Volatilite Alanında Yapılmış Lisansüstü Tezlere Yönelik Bir İçerik Analizi”, Muhasebe ve Finansman Dergisi, Ekim, ss.135-156.

Tektüfekçi, Fatma (2012), "Bilgi Teknolojilerinin Muhasebe Uygulamalarına Entegrasyonu ve Bütünleşik Sistemlerle Olan Etkileşim”, Organizasyon ve Yönetim Bilimleri Dergisi, Cilt 4, Sayı 2, ss.51-59.

Yalçın, Selçuk (2006), "Rekabet Avantajı Sağlamada Stratejik Maliyet Yönetiminin Muhasebe Uygulamalarıyla İlişkileri”, Dumlupınar Üniversitesi Sosyal Bilimler Dergisi, Sayı:15, Ağustos, ss. 15-34.

Yıldız, Şule-Tuna, Gülfen-Tuna, Vedat Ender (2016), "Kurumsal Sosyal Sorumluluk Kapsamında Çevre Açıklamaları İle Firma Özellikleri Arasındaki İlişki: Kimya, Petrol, Kauçuk ve Plastik Ürünler Sektöründe Bir Uygulama”, İşletme Araştırmaları Dergisi, 8/2, ss. 255- 276.

www.resmigazete.gov.tr.

www.yok.gov.tr

www.kgk.gov.tr 